\title{
Score Establishment and Brazilian Portuguese version of the Pregnancy Sexual Response Inventory (PSRI)
}

\section{Definição de escores e versão em português brasileiro do Inventário da Resposta Sexual na Gestação (PSRI)}

\author{
Cibele Vieira Cunha Rudge ${ }^{1}$ Iracema de Mattos Paranhos Calderon ${ }^{1}$ Ana Paula Machado de Almeida ${ }^{1}$ \\ Fernanda Piculo ${ }^{1}$ Marilza Vieira Cunha Rudge ${ }^{1}$ Angélica Mércia Pascon Barbosa ${ }^{1}$ \\ ${ }^{1}$ Department of Gynecology and Obstetrics, Universidade Estadual \\ Paulista Júlio de Mesquita Filho, Botucatu, SP, Brazil \\ Address for correspondence Angélica Mércia Pascon Barbosa, PhD, \\ Av. Higino Muzi Filho, 737, 17525-900, Mirante, Marília, \\ SP, Brazil (e-mail: angelicapascon@gmail.com).
}

Rev Bras Ginecol Obstet 2018;40:322-331.

\begin{abstract}
Keywords

- pregnancy

- sexuality

- questionnaires
\end{abstract}

Resumo
Objective To establish the Pregnancy Sexual Response Inventory (PSRI) scores for each domain before and during pregnancy, and to publish the Brazilian Portuguese version of the PSRI.

Methods Pregnant women were recruited during antenatal care; the PSRI was administered to 244 women prenatally at Faculdade de Medicina de Botucatu, at Universidade do Estado de São Paulo (UNESP, in the Portuguese acronym). The PSRI scores were estimated based on the Kings Health Questionnaire (KHQ) and the Medical Outcomes Study 36-item short form survey (SF-36). The raw scale type was used to standardize the minimal value and amplitude of each domain. For each domain, the score varied from 0 to 100 , and the composite score was obtained as the domain average. The composite score before and during pregnancy was determined by the sum of the scores of all specific domains for each divided by the full domain number. The categorization of the scale into quartiles was established when all PSRI-specific and composite scores were combined.

Results The composite and specific scores for each domain were categorized into quartiles: $0<25$ as "very bad;" $25<50$ as "bad;" $50<75$ as "good" and 75 to 100 as "excellent." The mean scores were lower during pregnancy than before pregnancy in 8 of the 10 domains. The Brazilian Portuguese PSRI version is presented.

Conclusion This study allowed the establishment of the PSRI composite and specific scores for each domain, and the categorization of scores into quartiles: very bad, bad, good and excellent. In addition, the Brazilian Portuguese version of the PSRI is presented in full for application in the Brazilian population.

Objetivo Estabelecer os escores do Inventário da Resposta Sexual na Gestação (PSRI) para cada domínio antes e durante a gravidez, e publicar a versão do PSRI em português brasileiro. received

October 24, 2017

accepted

April 19, 2018
DOI https://doi.org/

10.1055/s-0038-1656536. ISSN 0100-7203.
Copyright $\odot 2018$ by Thieme Revinter

Publicações Ltda, Rio de Janeiro, Brazil
License terms

(c) $(1) \$$ 
Métodos Gestantes foram recrutadas durante o cuidado pré-natal; o PSRI foi administrado a 244 mulheres no pré-natal na Faculdade de Medicina de Botucatu da Universidade do Estado de São Paulo (UNESP). Os escores do PSRI foram estimados com base no Kings Health Questionnaire (KHQ) e Medical Outcomes Study 36-item short form survey (SF-36). O tipo de escala bruta foi utilizado para padronizar o valor mínimo e a amplitude de cada domínio. Para cada domínio, a pontuação variou de 0 a 100 , e o escore composto foi obtido pela média do domínio. O escore composto antes e durante a gravidez foi determinado pela somatória dos escores de todos os domínios específicos para cada período dividido pelo número total do domínio. A escala de categorização em quartil foi estabelecida quando todos os escores específicos e compostos do PSRI foram reunidos.

Resultados Os escores compostos e específicos para cada domínio foram categorizados em quartis: $0<25$ como "muito ruim;" $25<50$ como "ruim;" $50<75$ como "bom" e 75 a 100 como "excelente." As médias dos escores foram menores durante a gravidez do que antes da gravidez em 8 dos 10 domínios. Foi apresentada a versão PSRI em português brasileiro.

Palavras-chave

- gestação

- sexualidade

- questionários
Conclusão Este estudo permitiu o estabelecimento dos escores compostos e específicos do PSRI para cada domínio e a categorização dos escores em quartis: muito ruim, ruim, bom e excelente. Além disso, a versão em português do PSRI é apresentada integralmente para aplicação na população brasileira.

\section{Introduction}

There are several maternal adaptations that involve profound anatomical, physiological, and biochemical changes, which may impact the sexual health of partners during pregnancy. ${ }^{1}$

A systematic review has found a gradual decrease in vaginal intercourse from prepregnancy to the first and third trimesters, ${ }^{2}$ and many studies have revealed a reduction in sexual function during pregnancy. ${ }^{1,3-5}$

This topic has attracted researchers' attention due to the increase in the number of epidemiological studies, but data are still limited on the prevalence of sexual dysfunction and concerns about sexual activity in pregnant women, and it remains unclear how to evaluate them. The female sex response cycle proposed by Basson $(2000)^{6}$ starts during a neutral phase, and the rewards of emotional closeness serve as the motivational factors that will activate the cycle the next time. This knowledge needs to be included in the instruments used to evaluate the sexual function during pregnancy. Moreover, there are some attitude changes toward sexual function during pregnancy, such as the different sexual responses proposed by Basson (2000), ${ }^{6}$ but the methodological limitations (sample sizes, unrepresentative samples, and retrospective data) and inconsistent results of published manuscripts may limit their relevance. ${ }^{7}$

Currently, the instrument "Pregnancy and Sexuality Questionnaire (PSQ)" has been developed to evaluate the subjectivity and complexity of sexual function within pregnancy, although the authors did not list the specific items included in their questionnaire within their article. ${ }^{8}$
The "Female Sexual Function Index (FSFI)" was developed to evaluate female sexual response; however, this questionnaire was not developed for pregnant women. ${ }^{9}$ In turn, the Pregnancy and Sexual Function Questionnaire (PSFQ), Portuguese version, was considered adequate for evaluating sexual function during pregnancy. ${ }^{10}$

The Pregnancy Sexual Response Inventory (PSRI) was designed based on the PSQ a validated instrument for studying sexual relations between partners during pregnan$c y,{ }^{8}$ and was integrated into the Basson ${ }^{6}$ sexual response. This instrument was developed due to the lack of access to the only instrument validated for studying the sexual relationship of partners within pregnancy.

There were five phases in the development of the PSRI: (I) item selection; (2) item development; (3) determination of internal consistency, reliability and convergence; (4) content validity; and (5) determination of inter-interviewer reliability. Internal consistency and reliability were evaluated using Cronbach's $\alpha$. Inter-interviewer reliability was assessed by evaluating the responses of 18 academics at various institutions using the Kappa Index and Student $t$-test. ${ }^{11}$ Furthermore, the PSRI was fully validated in the Brazilian Portuguese language by our current research group and covers different domains of sexual response during pregnancy. ${ }^{11}$ Although it is a validated questionnaire, the PSRI had not been published in Portuguese, and thus could not be used to support the clinical diagnosis of sexual function during pregnancy in Brazil and other Portuguese-speaking countries.

The aim of this study was to establish the PSRI composite and specific scores for each domain before and during pregnancy, and to publish the Brazilian Portuguese version of the PSRI. 


\section{Methods}

\section{Study Population}

An observational, cross-sectional, single-center study was performed between January and August 2016 at the Department of Gynecology and Obstetrics at the Faculdade de Medicina de Botucatu (FMB-UNESP, in the Portuguese acronym). This hospital is a tertiary center with a perinatal center of the highest level providing health services to medium- and high-risk obstetrical patients from an area with $\sim 500,000$ inhabitants, and 1,600 deliveries are performed in it per year. Healthy pregnant women seeking antenatal care were recruited to participate in the current study while waiting for their routine medical check-ups. Any patients who presented systemic illnesses, such as diabetes mellitus, hypertension, hyperlipidemia and thyroid dysfunction, and those who conceived by assisted reproduction techniques were excluded from the current study.

The protocol and the objectives of the study were explained to 370 pregnant women; 249 (67.3\%) of them provided a signed informed consent just before the administration of the validated instrument of sexual function - the PSRI. The eligibility criteria included healthy pregnant women who were heterosexual, 18 years of age or older, and in the second or third trimester of pregnancy and who had been sexually active in the previous 4 weeks.

Upon signing the informed consent, the eligible women were interviewed by a trained female interviewer using a paper-and-pencil standardized questionnaire. Interviews were conducted at the prenatal clinic in a private room. All women were assessed with a detailed medical history, including partnership status, education level, religion, employment status, parity, smoking habits, drinking, illicit drugs, planned pregnancy, and condom use, and a comprehensive physical examination was also performed for each woman. Our sample was mostly heterosexual, married, and in female-male relationships. The data were cross-sectional, which means we only collected one questionnaire per woman. Approval for the study was given by the local institutional research bureau under protocol number 161/2012.

\section{Questionnaire}

Sexual function was assessed using the PSRI. This semistructured questionnaire contained 38 questions divided into 12 questions about demographic traits and 26 questions about sexual behavior activity before and during pregnancy. The sexual response questions were grouped in 10 domains; eight of them assessed the women's feelings, and two assessed their perception of her partner's sexual interest. All domains included possible distress items, since it is necessary to investigate sexual dysfunction.

- Table 1 shows the questions grouped by domain for each period.

\section{Outcome Measures}

The primary outcomes were to make possible the establishment of scores to adequately evaluate the PSRI responses, and to publish the Portuguese version of the PSRI for application in the Brazilian population.
Table 1 Description of the grouped questions for each domain before and during pregnancy and the sum of all questions per domain

\begin{tabular}{|l|l|l|l|}
\hline Domains & Questions & Questions & Questions \\
\hline & $\begin{array}{l}\text { Before } \\
\text { pregnancy }\end{array}$ & $\begin{array}{l}\text { During } \\
\text { Pregnancy }\end{array}$ & All \\
\hline $\begin{array}{l}\text { PSRI (specific scores) } \\
\text { Female perception }\end{array}$ & $14 a$ & $\begin{array}{l}13,14 b, \\
14 c\end{array}$ & $\begin{array}{l}13,14 a, \\
14 b, 14 c\end{array}$ \\
\hline $\begin{array}{l}\text { Sexual activity } \\
\text { frequency }\end{array}$ & $21 a$ & $21 b, 22$ & $\begin{array}{l}21 a, 21 b, \\
22\end{array}$ \\
\hline Desire & $18 a$ & $18 b$ & $18 a, 18 b$ \\
\hline Arousal & $23 a$ & $23 b$ & $23 a, 23 b$ \\
\hline Orgasm & $15 a, 17 a$ & $15 b, 17 b$ & $\begin{array}{l}15 a, 15 b, \\
17 a, 17 b\end{array}$ \\
\hline $\begin{array}{l}\text { Satisfaction } \\
\text { Dyspareunia }\end{array}$ & $24 a$ & $24 b$ & $24 a, 24 b$ \\
\hline $\begin{array}{l}\text { Intercourse start } \\
\text { Female difficulties }\end{array}$ & 25a & $25 b$ & $25 a, 25 b$ \\
\hline $\begin{array}{l}\text { Female perception } \\
\text { of partners }\end{array}$ & & $19 b$ & $19 a, 19 b$ \\
\hline $\begin{array}{l}\text { Male sexual } \\
\text { satisfaction }\end{array}$ & $16 a$ & $16 b$ & $16 a, 16 b$ \\
\hline $\begin{array}{l}\text { Male sexual } \\
\text { difficulties }\end{array}$ & $26 a$ & $26 b$ & $26 a, 26 b$ \\
\hline
\end{tabular}

Abbreviation: PSRI, Pregnancy Sexual Response Inventory.

The numbers followed by letters are the number of questions that appear in the PSRI.

\section{PSRI Composite and Specific Score Establishment}

The estimated PSRI scores of sexual behavior considered all answers before and during pregnancy, with the answers divided into each domain according to period. Therefore, 11 questions were analyzed before pregnancy, while 14 questions were analyzed during pregnancy. Two composite scores for the PSRI were established according to both analyzed periods. A score was calculated for each domain in both periods. The $20^{\text {th }}$ question was not included in the score calculation because it was only answered if the $19^{\text {th }}$ question was marked "yes." Demographic characteristics were not included in the PSRI score calculation. The PSRI score estimate was based on the Kings Health Questionnaire $(\mathrm{KHQ})^{12}$ and the Medical Outcomes Study, a 36-item shortform health survey (SF-36). ${ }^{13}$ The raw scale type was used to standardize the minimal value and amplitude of each domain. For each domain, the score varied from 0 to 100 , and the general score was obtained using the domain average. The specific score for each domain was estimated using the SF-36 guidelines. ${ }^{13}$ The composite score comprising the periods before and during pregnancy was determined by adding the score of all specific domains for each period divided by the full domain number. Finally, we established the categorization scale into quartiles, once all the PSRIspecific and composite scores were combined (-Fig. 1). 


\begin{tabular}{|c|c|c|c|}
\hline \multicolumn{4}{|c|}{ Características Demográficas } \\
\hline \multicolumn{2}{|c|}{$\begin{array}{l}\text { 1- Idade Materna: } \\
\text { Idade do Parceiro: }\end{array}$} & \multicolumn{2}{|c|}{ 2- Idade Gestacional: } \\
\hline \multicolumn{2}{|c|}{$\begin{array}{l}\text { 3- Estado Civil: } \\
\text { (1) casada/união estável } \\
\text { (2) solteira } \\
\text { (3) outro }\end{array}$} & \multicolumn{2}{|c|}{$\begin{array}{l}\text { 4- Nível Educacional: } \\
\begin{array}{ll}\text { (1) } & \text { fundamental } \\
(2) & \text { ensino médio } \\
\text { (3) } & \text { ensino superior }\end{array}\end{array}$} \\
\hline \multicolumn{2}{|c|}{$\begin{array}{l}\text { 5- Religião: } \\
\text { (1) católica } \\
\text { (2) evangélica } \\
\text { (3) outras }\end{array}$} & \multicolumn{2}{|c|}{$\begin{array}{l}\text { 6- Você trabalha? } \\
\text { (1) não } \\
\text { (2) sim, eu tenho um trabalho } \\
\text { (3) sim, mas no momento estou } \\
\text { desempregada }\end{array}$} \\
\hline $\begin{array}{l}7-V \\
(1) \\
(2) \\
(3)\end{array}$ & $\begin{array}{l}\text { tem filhos? } \\
\text { não } \\
\text { apenas um } \\
\text { dois ou mais }\end{array}$ & $\begin{array}{l}\text { 8- } \\
(1) \\
(2) \\
(3)\end{array}$ & $\begin{array}{l}\text { fuma? } \\
\text { sim, com alguma ou muita frequência } \\
\text { sim, apenas as vezes } \\
\text { não }\end{array}$ \\
\hline $\begin{array}{l}9-V \\
(1) \\
(2) \\
(3)\end{array}$ & $\begin{array}{l}\text { bebe? } \\
\text { sim, com alguma ou muita frequência } \\
\text { sim, apenas às vezes } \\
\text { não }\end{array}$ & $\begin{array}{l}10- \\
(1) \\
(2) \\
(3)\end{array}$ & $\begin{array}{l}\text { ê usa drogas ilícitas? } \\
\text { sim, com alguma ou muita frequência } \\
\text { sim, apenas às vezes } \\
\text { não }\end{array}$ \\
\hline $\begin{array}{l}11- \\
(1) \\
(2)\end{array}$ & $\begin{array}{l}\text { ê planejou sua gravidez? } \\
\text { sim } \\
\text { não }\end{array}$ & $\begin{array}{l}12- \\
(1) \\
(2)\end{array}$ & $\begin{array}{l}\text { ê usa preservativo? } \\
\text { sim } \\
\text { não }\end{array}$ \\
\hline \multicolumn{4}{|c|}{ II- $\quad$ Comportamento/Atividade Sexual - antes e durante a gestação } \\
\hline $\begin{array}{l}\text { 13- } \\
\text { sex } \\
(1) \\
(2) \\
(3)\end{array}$ & $\begin{array}{l}\text { sua opinião, a frequência das suas relações } \\
\text { mudou depois que você engravidou? } \\
\text { sim, diminuiu } \\
\text { não, é a mesma } \\
\text { sim, aumentou }\end{array}$ & \multicolumn{2}{|c|}{$\begin{array}{l}\text { 14a- Antes da gestação, quantas vezes por semana } \\
\text { você tinha relações sexuais? } \\
\begin{array}{l}\text { (1) nenhuma } \\
\text { (2) } 1-2 \text { vezes } \\
\text { (3) } 3 \text { ou mais vezes }\end{array}\end{array}$} \\
\hline $\begin{array}{l}14 \mathrm{~b} \\
\text { por } \\
(1) \\
(2) \\
(3)\end{array}$ & $\begin{array}{l}\text { primeiro trimestre da gestação, quantas vezes } \\
\text { Iana você tinha relações sexuais? } \\
\text { nenhuma } \\
1-2 \text { vezes } \\
3 \text { ou mais }\end{array}$ & $\begin{array}{l}140 \\
\text { tem } \\
(1) \\
(2)\end{array}$ & $\begin{array}{l}\text { momento, quantas relações sexuais você } \\
\text { semana? } \\
\text { nenhuma } \\
1-2 \text { vezes } \\
3 \text { ou mais }\end{array}$ \\
\hline \multicolumn{2}{|c|}{$\begin{array}{l}\text { 15a- Como você classificaria sua vida sexual antes de } \\
\text { você engravidar? } \\
(0=\text { muito ruim, } 10 \text { = muito boa) }\end{array}$} & \multicolumn{2}{|c|}{$\begin{array}{l}\text { 15b- Como você classificaria sua vida sexual } \\
\text { atualmente? (0 = muito ruim, } 10=\text { muito boa) } \\
\begin{array}{l}\text { (1) } 0-3 \\
\text { (2) } 4-7 \\
\text { (3) } 8-10\end{array}\end{array}$} \\
\hline
\end{tabular}

Fig. 1 Full version of the Brazilian Portuguese Pregnancy Sexual Response Inventory. 
326 Score Establishment and Brazilian Portuguese version of the PSRI Rudge et al.

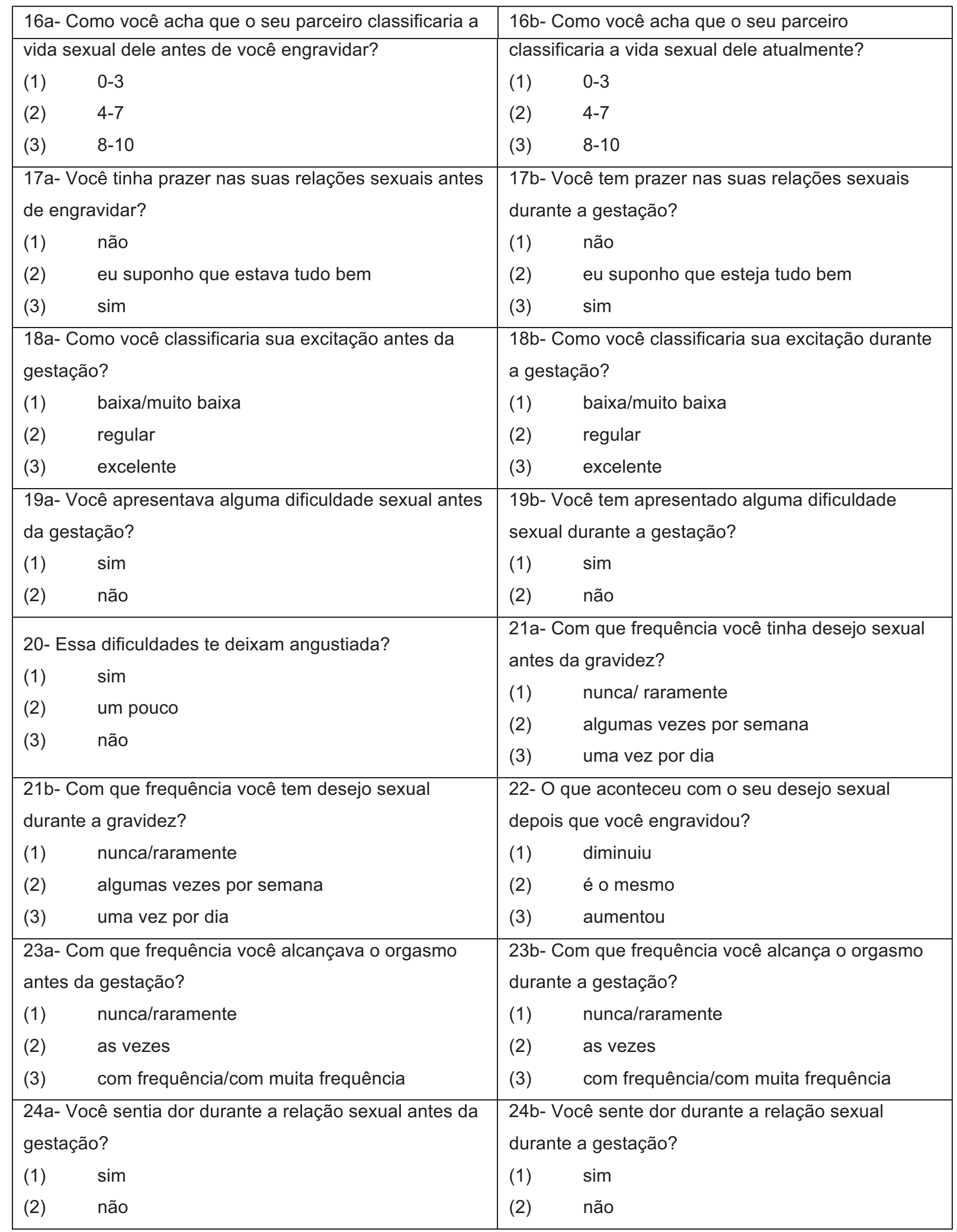

Fig. 1 (Continued) 


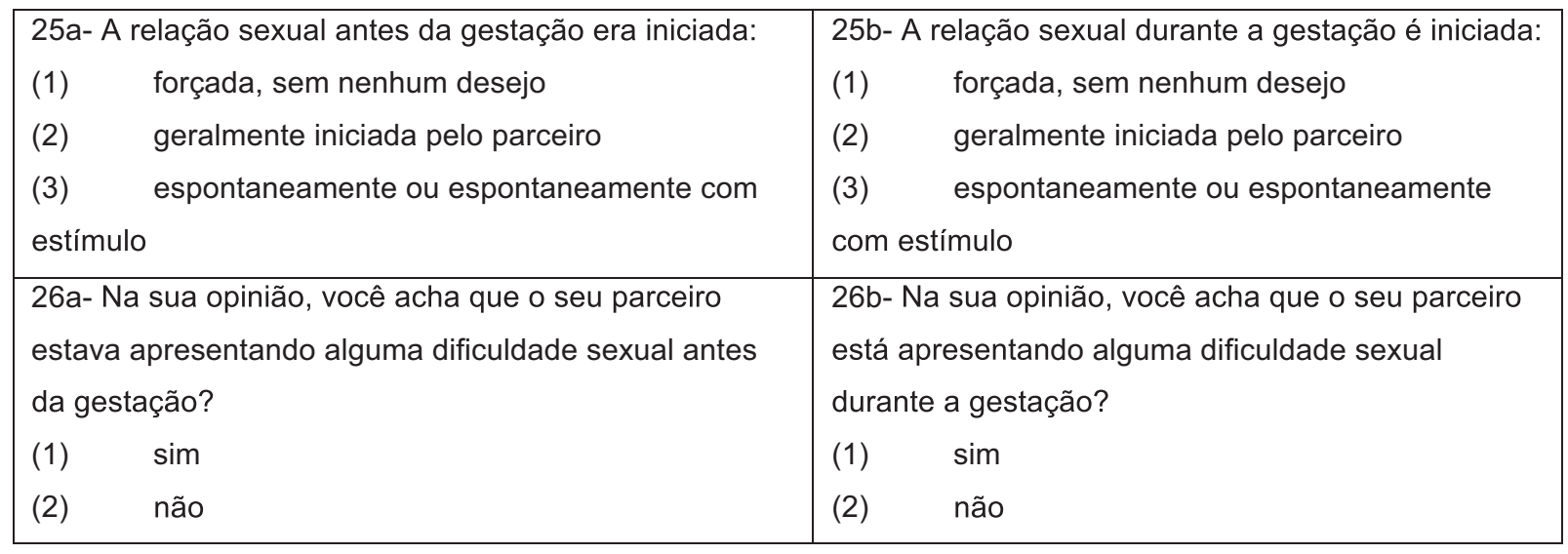

Fig. 1 (Continued)

\section{Portuguese Version}

The Brazilian Portuguese version of the PSRI is presented in the same format as the English one.

\section{Statistical Analyses}

The sample size was calculated according to the $40 \%$ prevalence of sexual dysfunction in pregnant women, with a margin of error of $10 \%$ and a reliability of $95 \%{ }^{14}$ Thus, the minimum sample size was determined to be184 participants.

Comparisons between means of the domain values classified by both analyzed periods were assessed by paired $t$ test at a significance level of 5\%. All data were analyzed using the software Statistical Analysis System (SAS) for Windows, version 9.2 (SAS Institute Inc., Cary, NC, USA).

\section{Results}

-Fig. 2 provides an overview of the study sample collection. The Brazilian Portuguese PSRI, a validated questionnaire, is shown in - Fig. 1. Two hundred and forty-nine pregnant women completed the PSRI, with 49 in the second trimester of pregnancy, 200 in the third trimester of pregnancy and 5 excluded from the final sample because their questionnaires were incomplete. -Table $\mathbf{2}$ represents the demographic features of our full sample. The mean maternal age of the 244 participants was 26 years $(S D=5.4$, Min $=20.6$, Max $=31.4$ ). At study inclusion, the mean gestational age was 34.8 weeks of pregnancy $(S D=3.5, \quad$ Min $=25.0$, Max $=42.0)$. The majority of our sample $(63.1 \%)$ was married

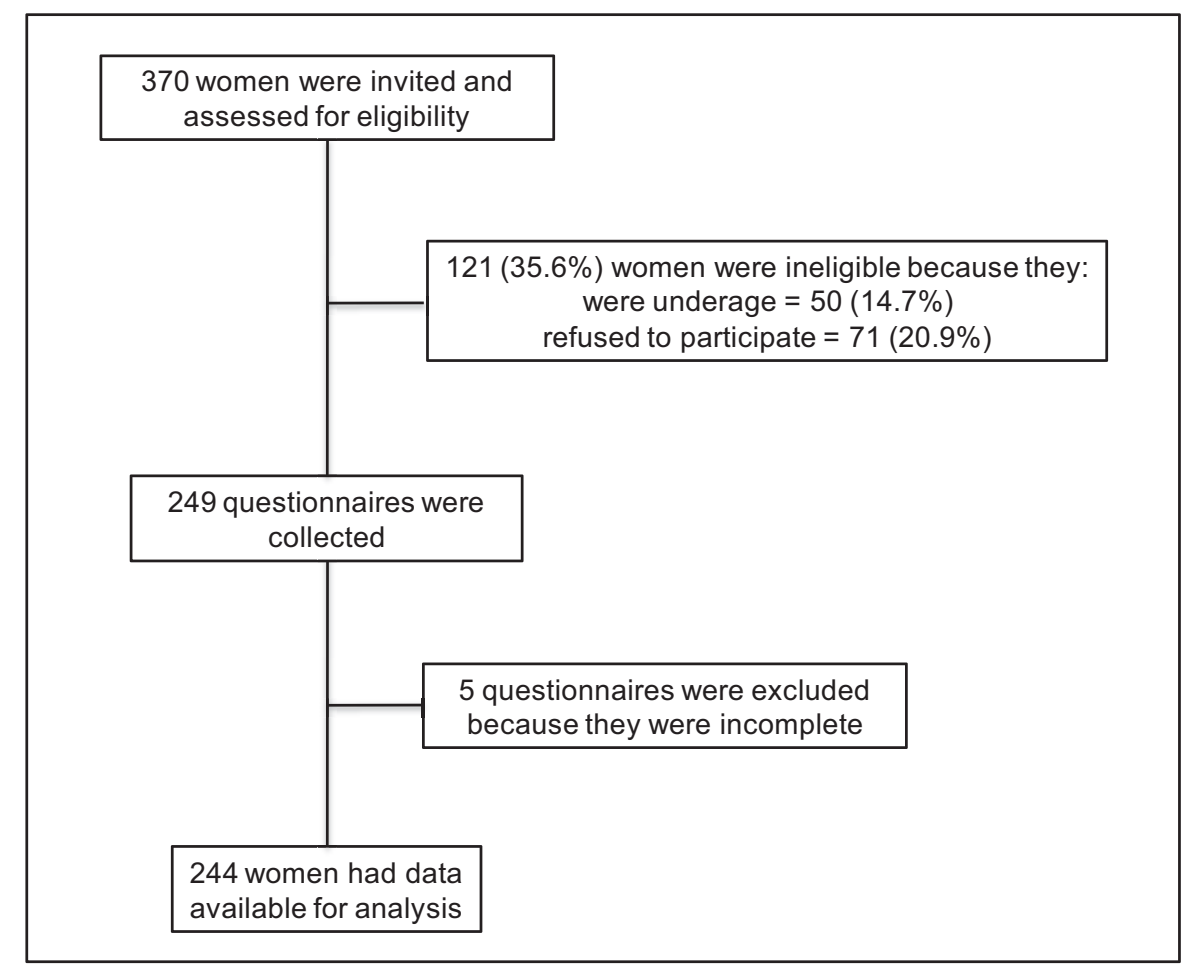

Fig. 2 Flow-diagram describing the process for recruitment of the pregnant women. 
Table 2 Descriptive demographic characteristics of pregnant women

\begin{tabular}{|c|c|}
\hline Variables & $f(\%)$ \\
\hline \multicolumn{2}{|l|}{ Partnership status } \\
\hline Married/Living together & $154(63.1)$ \\
\hline Single & $71(2.1)$ \\
\hline Other & $19(7.8)$ \\
\hline \multicolumn{2}{|l|}{ Sociodemographic factors } \\
\hline \multicolumn{2}{|l|}{ Education Level } \\
\hline Basic Level & $99(40.6)$ \\
\hline High School & $120(49.2)$ \\
\hline College/University & $25(1.2)$ \\
\hline \multicolumn{2}{|l|}{ Religion } \\
\hline Catholic & $113(46.3)$ \\
\hline Brazilian Protestants & $95(38.9)$ \\
\hline Other/No religion & $36(14.8)$ \\
\hline \multicolumn{2}{|l|}{ Employment status } \\
\hline Student & $72(29.5)$ \\
\hline Employed & $86(35.2)$ \\
\hline Not employed & $86(35.2)$ \\
\hline \multicolumn{2}{|l|}{ Children } \\
\hline No & $128(52.5)$ \\
\hline Just one & $71(29.1)$ \\
\hline Two or more & $45(18.4)$ \\
\hline \multicolumn{2}{|l|}{ Smoke } \\
\hline Often/Very often & $20(8.2)$ \\
\hline Sometimes & $21(8.6)$ \\
\hline No & $203(83.2)$ \\
\hline \multicolumn{2}{|l|}{ Drink } \\
\hline Often/Very often & $2(0.8)$ \\
\hline Sometimes & $11(4.5)$ \\
\hline No & $231(94.7)$ \\
\hline \multicolumn{2}{|l|}{ Illicit drugs } \\
\hline Often/Very often & $5(2.0)$ \\
\hline Sometimes & $2(0.8)$ \\
\hline No & $237(97.1)$ \\
\hline \multicolumn{2}{|l|}{ Family planning knowledge } \\
\hline \multicolumn{2}{|l|}{ Planned pregnancy } \\
\hline Yes & $109(44.7)$ \\
\hline No & $135(55.3)$ \\
\hline \multicolumn{2}{|l|}{ Contraceptive methods* } \\
\hline No & $199(81.6)$ \\
\hline Yes, stopped before pregnancy & $28(11.5)$ \\
\hline Very often & $17(7.0)$ \\
\hline
\end{tabular}

Abbreviation: $\mathrm{f}$, frequency of clinical characteristics of the study population.

or living together, primigravida (52.5\%) and had studied until elementary school (59.4\%). From our sample, $40.6 \%$ were Catholic, 38.9\% were Brazilian Protestants, and the rest answered another or no religion. A high proportion of the respondents were students (29.5\%) and employed full- or part-time (35.2\%). Only a small percentage (16.8\%) reported smoking at least half a pack of cigarettes per day, and 94.7\% responded that they did not drink alcohol even socially. A history of illicit drug use was observed in $2.8 \%$ of all respondents. A high percentage of our sample (55.3\%) declared that pregnancy was unplanned, and $81.6 \%$ did not use condoms. Additional assessed demographics can be seen in - Table 2.

\section{Composite and Specific Scores Measured by Domains for PSRI}

-Fig. 3 shows the questions grouped by each domain and by each period, and the composite score for the PSRI specific score measurements before and during pregnancy in the studied population. As the options for the PSRI answers are graduated from minimal to maximal values, " 0 " is considered the worst and " 100 " the best. These values are the inverse of the KHQ for which the answer options are graduated from "best" to "worse" values.

The score was categorized into quartiles by sexual response as follows: $0<25$ as "very bad," $25<50$ as "bad," $50<75$ as "good" and 75 to 100 as "excellent." Using this established quartile-categorized score for PSRI composite scores before and during pregnancy allowed us to accurately identify the quality of the answers of each domain and the sum of the domains of the composite score (-Fig. 3 ).

\section{Influence of Pregnancy on Sexual Response as Evaluated by the PSRI}

-Table 3 shows the results of the specific and composite scores before and during pregnancy. During pregnancy, the specific scores were lower than before pregnancy in almost all of the PSRI domains (sexual activity frequency, arousal, orgasm, satisfaction, dyspareunia, intercourse start, female difficulties and male sexual satisfaction) $(p<0.05)$, thus suggesting a negative impact of pregnancy on sexual function response. A significant increase in the desire score was observed, but no significant difference in male sexual difficulties was shown between the periods. The composite score of sexual activity as evaluated by the PSRI showed a significant decrease from pre-pregnancy (mean score $=83$ "excellent") to during pregnancy (mean score = 66 "good").

\section{Discussion}

Sexual function during pregnancy is an aspect of quality of life. The World Health Organization defined sexual health as "a state of physical, emotional, mental, and social wellbeing related to sexuality." 15 Sexual dysfunctions are defined as disorders related to both sexual desire and sexual satisfaction for several reasons. ${ }^{16}$

Pregnancy is a process of alteration experienced by women, and as a consequence, sexual life also changes during pregnancy, ${ }^{17}$ although there is a lack of specific instruments in the literature to confirm the influence of pregnancy on sexual function. Many non-specific questionnaires to characterize this adjustment of sexual function in pregnant women have been published. ${ }^{18}$ The FSFI questionnaire has been used to 


\begin{tabular}{|c|c|}
\hline PSR & cific Score \\
\hline Before pregnancy & During pregnancy \\
\hline $\begin{array}{l}\text { Frequency score } \\
\qquad F S=\frac{(Q 14 a-1)}{2} \times 100\end{array}$ & $\begin{array}{l}\text { Frequency Score } \\
\qquad F S=\frac{[(Q 13+Q 14 b+Q 14 c)-3]}{6} \times 100\end{array}$ \\
\hline $\begin{array}{l}\text { Desire Score } \\
\qquad D S=\frac{(Q 21 a-1)}{2} \times 100\end{array}$ & $\begin{array}{l}\text { Desire Score } \\
\qquad D S=\frac{[(Q 21 b+Q 22)-2]}{4} \times 100\end{array}$ \\
\hline $\begin{array}{l}\text { Arousal Score } \\
\qquad A S=\frac{(Q 18 a-1)}{2} \times 100\end{array}$ & $\begin{array}{l}\text { Arousal Score } \\
\qquad A S=\frac{(Q 18 b-1)}{2} \times 100\end{array}$ \\
\hline $\begin{array}{l}\text { Orgasm Score } \\
\qquad O S=\frac{(Q 23 a-1)}{2} \times 100\end{array}$ & $\begin{array}{l}\text { Orgasm Score } \\
\qquad O S=\frac{(Q 23 b-1)}{2} \times 100\end{array}$ \\
\hline $\begin{array}{l}\text { Satisfaction Score } \\
\qquad S S=\frac{[(Q 15 a+Q 17 a)-2]}{4} \times 100\end{array}$ & $\begin{array}{l}\text { Satisfaction Score } \\
\qquad S S=\frac{[(Q 15 b+Q 17 b)-2]}{4} \times 100\end{array}$ \\
\hline $\begin{array}{l}\text { Dyspareunia Score } \\
\qquad \text { DyS }=(Q 24 a-1) \times 100\end{array}$ & $\begin{array}{l}\text { Dyspareunia Score } \\
\qquad \text { DyS }=(Q 24 b-1) \times 100\end{array}$ \\
\hline $\begin{array}{l}\text { Intercourse Start Score } \\
\qquad I S S=\frac{(Q 25 a-1)}{2} \times 100\end{array}$ & $\begin{array}{l}\text { Intercourse Start Score } \\
\qquad I S S=\frac{(Q 25 b-1)}{2} \times 100\end{array}$ \\
\hline $\begin{array}{l}\text { Female Difficulties Score } \\
\qquad F D S=(Q 19 a-1) \times 100\end{array}$ & $\begin{array}{l}\text { Female Difficulties Score } \\
\qquad F D S=(Q 19 b-1) \times 100\end{array}$ \\
\hline $\begin{array}{l}\text { Male sexual satisfaction score } \\
\qquad M S S S=\frac{(Q 16 a-1)}{2} \times 100\end{array}$ & $\begin{array}{l}\text { Male sexual satisfaction score } \\
\qquad \text { MSSS }=\frac{(Q 16 b-1)}{2} \times 100\end{array}$ \\
\hline $\begin{array}{l}\text { Male difficulties score } \\
\qquad M D S=(Q 26 a-1) \times 100\end{array}$ & $\begin{array}{l}\text { Male difficulties score } \\
\qquad M D S=(Q 26 b-1) \times 100\end{array}$ \\
\hline \multicolumn{2}{|c|}{ Composite Score $=\frac{F S+D S+A S+O S+S S+D y S+I S}{10}$} \\
\hline
\end{tabular}

Fig. 3 Pregnancy Sexual Response Inventory I composite and specific scores for each domain before and during pregnancy.

assess sexual function, showing low values in the third trimester. ${ }^{19,20}$ However, it is essential to emphasize that the current and most frequent use of the FSFI is for non-pregnant women, for whom it was designed and validated. The PSRI is a specific questionnaire that was designed to consider the influence of pregnancy on sexual behavior using a self-evaluation before and during pregnancy. This differences in the design and drafting of the questionnaires need to be taken into account when considering the disparities in the results published in various articles, which result in a lack of consensus.

The findings presented here in our study using the PSRI indicate that the composite and specific scores for each 
Table 3 Pregnancy Sexual Response Inventory composite and specific scores before and during pregnancy

\begin{tabular}{|l|l|l|l|}
\hline \multirow{2}{*}{ Domains } & $\begin{array}{l}\text { Before } \\
\text { pregnancy }\end{array}$ & $\begin{array}{l}\text { During } \\
\text { pregnancy }\end{array}$ & \multirow{2}{*}{ Value } \\
\cline { 2 - 3 } & Mean \pm SD & Mean \pm SD & \\
\hline $\begin{array}{l}\text { Frequency } \\
\text { score }\end{array}$ & $72.95 \pm 28.63$ & $43.83 \pm 29.4$ & $0.0 *^{*}$ \\
\hline Desire score & $48.58 \pm 42.23$ & $63.61 \pm 27.7$ & $0.02^{*}$ \\
\hline Arousal score & $79.18 \pm 27.1$ & $54.63 \pm 31.56$ & $0.00^{*}$ \\
\hline Orgasm score & $95.55 \pm 16.57$ & $72.95 \pm 34.04$ & $0.00^{*}$ \\
\hline $\begin{array}{l}\text { Satisfaction } \\
\text { score }\end{array}$ & $86.3 \pm 19.68$ & $64.06 \pm 30.58$ & $0.00^{*}$ \\
\hline $\begin{array}{l}\text { Dyspareunia } \\
\text { score }\end{array}$ & $89.68 \pm 30.48$ & $70.11 \pm 45.86$ & $0.00^{*}$ \\
\hline $\begin{array}{l}\text { Intercourse } \\
\text { start score }\end{array}$ & $85.23 \pm 23.24$ & $81.67 \pm 24.5$ & $0.01^{*}$ \\
\hline $\begin{array}{l}\text { Female } \\
\text { difficulties } \\
\text { score }\end{array}$ & $92.52 \pm 26.34$ & $67.61 \pm 46.88$ & $0.0 *^{*}$ \\
\hline $\begin{array}{l}\text { Male sexual } \\
\text { satisfaction } \\
\text { score }\end{array}$ & $82.74 \pm 30.69$ & $49.46 \pm 40.85$ & $0.0 *^{*}$ \\
\hline $\begin{array}{l}\text { Male sexual } \\
\text { difficulties } \\
\text { score }\end{array}$ & $97.15 \pm 16.66$ & $95.73 \pm 20.25$ & 0.13 \\
\hline $\begin{array}{l}\text { Composite } \\
\text { score }\end{array}$ & $82.99 \pm 9.76$ & $66.25 \pm 15.14$ & $0.00^{*}$ \\
\hline
\end{tabular}

Abbreviation: SD, standard deviation. ${ }^{*} P<0.05$.

domain and from prepregnancy to pregnancy were established. The scores were significantly different and categorized into quartiles by sexual response as follows: $0<25$ as "very bad," $25<50$ as "bad," $50<75$ as "good" and 75 to 100 as "excellent" for before and during pregnancy. The results indicated that lower composite and specific scores occurred during pregnancy than before pregnancy in almost all PSRI domains (sexual activity frequency, arousal, orgasm, satisfaction, dyspareunia, intercourse start, female difficulties and male sexual satisfaction).

These results may indicate the negative impact of pregnancy on sexual function response. However, some authors demonstrated no difference in general scores between the $1^{\text {st }}$ and $2^{\text {nd }}$ trimesters but a significant association between decreased intercourse frequency and trimesters. ${ }^{4}$ Galazka et al $(2015)^{5}$ found that desire, arousal, lubrication, orgasm, satisfaction, pain and sexual activity frequency decrease as gestation advances. Most of our findings are in line with the recent literature, which characterizes the perinatal period by a low sex drive. ${ }^{21,22}$ Women also seem to report higher levels of FSD female sexual dysfunction and low sexual desire, which is potentially associated with overall physical discomfort. ${ }^{23,24}$

Our results suggest that it is possible to quantitatively assess the impact of pregnancy on sexual response through score estimations before and during pregnancy, allowing comparisons of women's real sexual state during different pregnancy periods. As hypothesized, the PSRI scores could allow us to understand the influence of pregnancy on sexual health not only in qualitative but also in quantitative parameters for each domain. By using scores, clinicians can better plan and implement strategies and health programs targeted at improving sexual health for pregnant partners.

Identifying pregnant women who experience sexual distress and referring them to appropriate resources could help to minimize sexual and relationship problems during pregnancy. ${ }^{25}$ These strategies are important not only for clinical assistance but also to teach and train undergraduates of medicine because most of them do not feel comfortable or confident, and they lack specific knowledge and skills to address questions related to sexual problems within pregnancy. ${ }^{26}$

Despite fears and myths about sexual activity during pregnancy, maintaining sexual interactions throughout the pregnancy and postpartum period can promote sexual health, well-being and a greater depth of intimacy. An open discussion about the expected changes in sexual health could provide guidance for couples, as well as promote rigorously designed, evidence-based studies to further elucidate our understanding of sexual function during pregnancy and postpartum. ${ }^{27}$

Although far from conclusive, these results are consistent with the hypothesis that a clinical diagnostic assessment using PSRI scores enables and facilitates an understanding of the current pregnancy sexual response and changes in sexual response before and during pregnancy. Our results, in particular, can indicate that clinical scores may represent a key strategy for implementing specific health programs to improve sexual health for pregnant partners.

As with many studies, it is important to consider the potential strengths and weaknesses of the clinical PSRI scores, as well as their use in further clinical practice and research implications.

The current study's strength relies on the use of a validated instrument to assess sexual function during pregnancy. ${ }^{11}$ We acknowledge that using additional questionnaires to evaluate the sexual symptoms and quality of life of the participants could have enriched our study. Finally, the current study's limitations involve our sample, which mostly comprised heterosexual married women, which prevents our findings from being extrapolated to a broader population of pregnant women. More studies involving women of other social and cultural contexts are needed to confirm such findings. As the PSRI is a generic questionnaire, its value for pregnancy comorbidities should be investigated.

Despite these limitations, the current study advances the understanding of the inter-relationships between maternal sexual response before and during pregnancy. As such, our findings regarding the clinical scores for the potential classification of pregnant women's sexual dysfunction may have implications for evidence-based practice in preventative and intervention efforts, as well as in scientific study. The ultimate goal would be to implement early treatment and support (ideally before pregnancy) to improve the couple's sexual health outcomes. Further studies are needed to establish the cutoff score to be used to indicate normal sexual function during pregnancy and sexual dysfunction during pregnancy. 
Nonetheless, there are several important clinical implications of our findings. First, the current study enriches the literature because a validated questionnaire can establish clinically meaningful scores, supporting the efforts of other nations to translate and apply such instruments in specific pregnancy comorbidities. Additionally, we can encourage healthcare providers to use the PSRI scores for composite and specific domains to determine the influence of pregnancy on each one of the sexual response domains. Finally, the PSRI is a unique validated instrument designed specifically to evaluate at the same time the sexual response before and during pregnancy.

The Brazilian Portuguese version of the PSRI is published within the current manuscript, which allows Portuguese speakers to administer the questionnaire during antenatal care. According to the results, pregnant women or couples would be referred to a sexologist.

\section{Conclusion}

This study allowed the establishment of PSRI composite and specific scores for each domain, between 0 and 100 , and the categorization of scores into quartiles: very bad, bad, good and excellent. In addition, the Portuguese version of the PSRI is presented in full for application in the Brazilian population.

\section{Contributors}

Rudge C. V. C., Calderon I. M. P., Almeida A. P. M., Piculo F., Rudge M. V. C. and Barbosa A. M. P. contributed with the project and interpretation of data, writing of the article, critical review of the intellectual content and final approval of the version to be published.

\section{Conflicts of Interest}

No conflicts of interest have been declared by the authors.

Acknowledgments

This study was funded by Fundação de Amparo à Pesquisa do Estado de São Paulo (FAPESP, in the Portuguese acronym), grants 2012/25207-4 and 2012/15577-9.

\section{References}

1 Staruch M, Kucharczyk A, Zawadzka K, Wielgos M, Szymusik I. Sexual activity during pregnancy. Neuroendocrinol Lett 2016;37(01):53-58

2 Jawed-Wessel S, Sevick E. The impact of pregnancy and childbirth on sexual behaviors: a systematic review. J Sex Res 2017;54(45):411-423. Doi: 10.1080/00224499.2016.1274715

3 Aydin M, Cayonu N, Kadihasanoglu M, Irkilata L, Atilla MK, Kendirci M. Comparison of sexual functions in pregnant and non-pregnant women.Urol J2015;12(05):2339-2344. Doi: 10.22037/uj.v12i5.2881

4 Corbacioglu Esmer A, Akca A, Akbayir O, Goksedef BP, Bakir VL. Female sexual function and associated factors during pregnancy. J Obstet Gynaecol Res 2013;39(06):1165-1172. Doi: 10.1111/jog.12048

5 Gałązka I, Drosdzol-Cop A, Naworska B, Czajkowska M, Skrzypulec-Plinta V. Changes in the sexual function during pregnancy. J Sex Med 2015;12(02):445-454. Doi: 10.1111/jsm.12747

6 Basson R. The female sexual response: a different model. J Sex Marital Ther 2000;26(01):51-65. Doi: 10.1080/009262300278641

7 Bartellas E, Crane JM, Daley M, Bennett KA, Hutchens D. Sexuality and sexual activity in pregnancy. BJOG 2000;107(08):964-968. Doi: 10.1111/j.1471-0528.2000.tb10397.x
8 Barclay L, Bond M, Clark M. Development of an instrument to study the sexual relationship of partners during pregnancy. Aust J Adv Nurs 1992-1993;10(02):14-21

9 Rosen R, Brown C, Heiman J, et al. The Female Sexual Function Index (FSFI): a multidimensional self-report instrument for the assessment of female sexual function. J Sex Marital Ther 2000;26 (02):191-208. Doi: 10.1080/009262300278597

10 Amaral TL, Monteiro GT. [Translation and validation of the Pregnancy and Sexual Function Questionnaire (PSFQ)]. Rev Bras Ginecol Obstet 2014;36(03):131-138. Doi: 10.1590/S0100-72032014000300007

11 Rudge CV, Calderon IM, Dias A, et al. Design and validity of a questionnaire to assess sexuality in pregnant women. Reprod Health 2009;6:12. Doi: 10.1186/1742-4755-6-12

12 Tamanini JT, D'Ancona CA, Botega NJ, Rodrigues Netto N Jr. [Validation of the Portuguese version of the King's Health Questionnaire for urinary incontinent women]. Rev Saude Publica 2003;37(02): 203-211. Doi: 10.1590/S0034-89102003000200007

13 Stewart M. The Medical Outcomes Study 36-item short-form health survey (SF-36). Aust J Physiother 2007;53(03):208. Doi: 10.1016/S0004-9514(07)70033-8

14 Leite AP, Campos AA, Dias AR, Amed AM, De Souza E, Camano L. Prevalence of sexual dysfunction during pregnancy. Rev Assoc Med Bras (1992) 2009;55(05):563-568. Doi: 10.1590/S010442302009000500020

15 World Health Organization. Defining Sexual Health: Report of a Technical Consultation on Sexual Health 28-31 January 2002. Geneva: WHO; 2006

16 Laumann EO, Paik A, Rosen RC. Sexual dysfunction in the United States: prevalence and predictors. JAMA 1999;281(06):537-544. Doi: $10.1001 /$ jama.281.6.537

17 Gökyildiz S, Beji NK. The effects of pregnancy on sexual life. J Sex Marital Ther 2005;31(03):201-215. Doi: 10.1080/009262305905 13410

18 Leite APL, Moura EA, Campos AAS, Mattar R, Souza E, Camano L. [Validation of the Female Sexual Function Index in Brazilian pregnant women]Rev Bras Ginecol Obstet 2007;29:396-401. Doi: 10.1590/S0100-72032007000800003

19 Ribeiro MC, Nakamura MU, Torloni MR, Scanavino MdeT, Scomparini FB, Mattar R. Female sexual function of overweight women with gestational diabetes mellitus - a cross-sectional study. PLoS One 2014;9(04):e95094. Doi: 10.1371/journal.pone.0095094

20 Aslan G, Aslan D, Kizilyar A, Ispahi C, Esen A. A prospective analysis of sexual functions during pregnancy. Int J Impot Res 2005;17(02):154-157

21 Aslan E, Beji NK, Gungor I, Kadioglu A, Dikencik BK. Prevalence and risk factors for low sexual function in women: a study of 1,009 women in an outpatient clinic of a university hospital in Istanbul. J Sex Med 2008;5(09):2044-2052. Doi: 10.1111/ j.1743-6109.2008.00873.x

22 Erol B, Sanli O, Korkmaz D, Seyhan A, Akman T, Kadioglu A. A crosssectional study of female sexual function and dysfunction during pregnancy. J Sex Med 2007;4(05):1381-1387. Doi: 10.1111/j.17436109.2007.00559.x

23 DeJudicibus MA, McCabe MP. Psychological factors and the sexuality of pregnant and postpartum women. J Sex Res 2002;39(02): 94-103. Doi: 10.1080/00224490209552128

24 Byrd JE, Hyde JS, DeLamater JD, Plant EA. Sexuality during pregnancy and the year postpartum. J Fam Pract 1998;47(04): 305-308. Doi: 10.1080/00224499609551826

25 Vannier SA, Rosen NO. Sexual distress and sexual problems during pregnancy: associations with sexual and relationship satisfaction. J Sex Med 2017;14(03):387-395

26 Vieira TC, de Souza E, Abdo CH, et al. Brazilian residents' attitude and practice toward sexual health issues in pregnant patients. J Sex Med 2012;9(10):2516-2524. Doi: 10.1111/j.1743-6109.2012.02809.x

27 Johnson CE. Sexual health during pregnancy and the postpartum. J Sex Med 2011;8(05):1267-1284, quiz 1285-1286. Doi: 10.1111/ j.1743-6109.2011.02223.x 